「材料」(J. Soc. Mat. Sci., Japan), Vol. 44, No. 500, pp. 557-561, May 1995

論文

\title{
鋼道路橋の疲労設計のための垂直補剛材 取付け部の変動荷重実験
}

\author{
坂 野 昌 弘* 三上市藏** \\ 鹿野 顕 一*** 米本栄 一**** \section{for Fatigue Design of Steel Highway Bridges} \\ Variable Amplitude Loading Test of Transverse Stiffener Joints
}

by

\author{
Masahiro SAKANO*, Ichizo MiKAMI ${ }^{* *}$, Ken'ichi KANO*** \\ and Eiichi Yonemoto****
}

\begin{abstract}
A long-life variable amplitude fatigue test is performed using plate girder specimens with four types of transverse stiffener connections under highway traffic loading. Fatigue cracks are initiated from the fillet weld toe at the stiffener end on both the tension side and compression side, from blow holes contained in web-to-flange longitudinal fillet welds, and from the transverse fillet weld toe of the patch plate on the compression flange. The fatigue failure life of all four details of the transverse stiffener connections satisfies the condition of JSSC category D.
\end{abstract}

Key words : Fatigue test, Variable amplitude, Highway bridge, Transverse stiffener joint

\section{1 は じめ に}

1990年の道路橋示方書の改訂により，鋼プレートガー ダーの引張フランジへの垂直補剛材の取付け方法が新た に規定された. すなわち, 疲労への配慮から, 支点部以 外では原則として引張フランジと垂直補剛材は溶接しな いこととし, 荷重集中点では密着させ, 荷重集中点以外 ではさらに防錆に配慮して適当な間隔をあけて取付ける ものとした. 一方, 桁面外方向の水平力を垂直補剛材を 介して伝達する場合や引張フランジが床版に接する場合 などでは, 引張フランジと垂直補剛材は溶接することと 規定している. もとょり, 道路橋示方書では鋼床版以外 の一般的な部材に対する疲労照査法は規定されていない ため, それら垂直補剛材取付け部の疲労強度の違いに関 する記述はみられないが, 疲労き裂の発生・成長が桁全 体の崩壊につながるおそれのあるそのような引張フラン ジ付近のディテールに関しては, その疲労挙動を十分に 把握しておくことが重要である.

このような応力直角方向に設けられた補剛材取付け部 の疲労強度を評価する場合, 荷重非伝達型十字継手試験 体の疲労試験結果を基準として用いるのが一般的である. しかしながら, 実際の接合部にはスカーラップや回し溶 接, 溶接線の交差部などが存在しており, 小型の継手試 験体ではそれらの影響を忠実に再現するのは不可能であ る.また，ディテールによっては溶接施工性に差があり， それらが疲労強度に影響を及ぼすことも予想される.し たがって, 実物大の垂直補剛材取付け部を忠実に再現し
た大型試験体を製作し，それらを用いて疲労実験を行う 必要がある。

著者らは以前, 4 種類の垂直補剛材取付けディテール を有するプレートガーダー試験体を用いて一定振幅荷重 による疲労実験を行い, 各取付ディテールの疲労挙動に ついて比較検討した。.しかしながら, 現実に交通荷重に より道路橋の主要部材に生じる応力変動の大部分は一定 振幅応力下の疲労限よりも小さいものであり, そのよう な変動応力下における疲労挙動の違いを明らかにするこ とが実用上は重要となる，本研究では，道路橋部材に実 際に作用する変動荷重を模したシミュレーション変動荷 重波形を用いて文献 3 ）と同様なプレートガーダー試験 体の疲労実験を行い, 道路橋変動荷重下における垂直補 剛材取付け部の疲労き裂発生進展挙動および疲労強度特 性について検討する。

$$
2 \text { 実 験 方 法 }
$$

\section{$2 \cdot 1$ 試験体}

試験体の形状と寸法を Fig. 1 に示す. 今回の変動荷重 疲労実験で使用した試験体は 2 体 (No. 4 と No. 5 ) で ある. それぞれ一定振幅疲労実験で用いた試験体 (No. 1〜No. 3），と同一条件で製作したものであり，全長 $3 \mathrm{~m}$, 高さ約 $0.4 \mathrm{~m}$ のI 型断面プレートガーダーの 4 か所に, それぞれ以下の 4 種類の方法で垂直補剛材を取付けてい る.

(1.) スカーラップを設け, 引張フランジと溶接する

(2) スカーラップを設け, 引張フランジと密着させる 


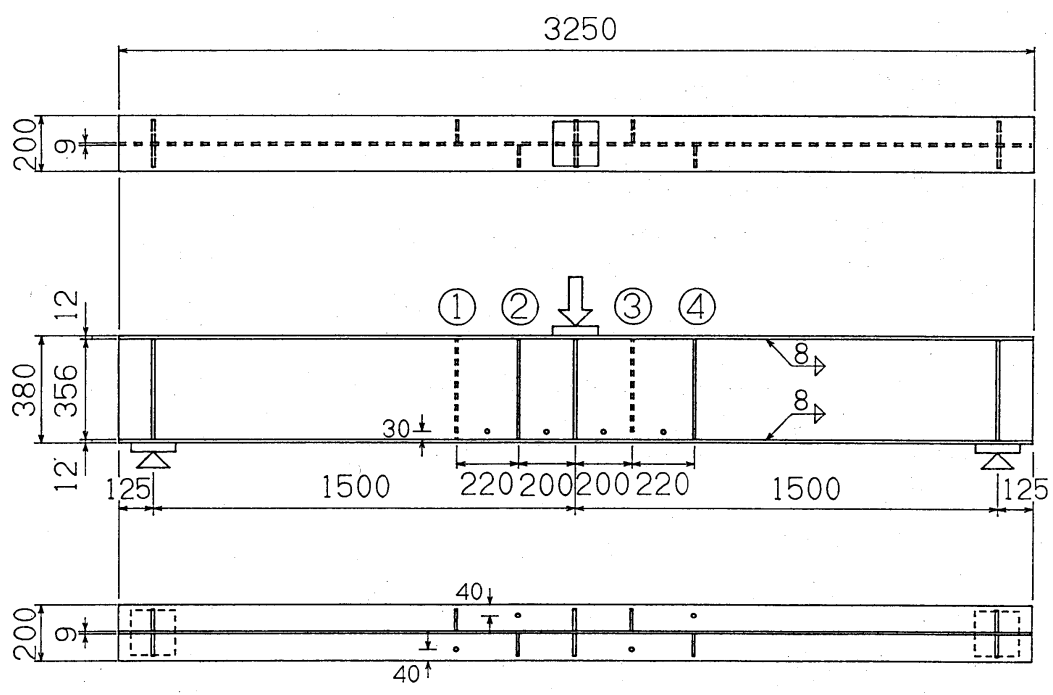

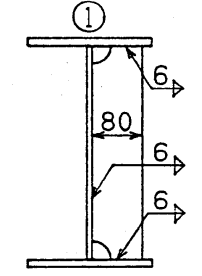
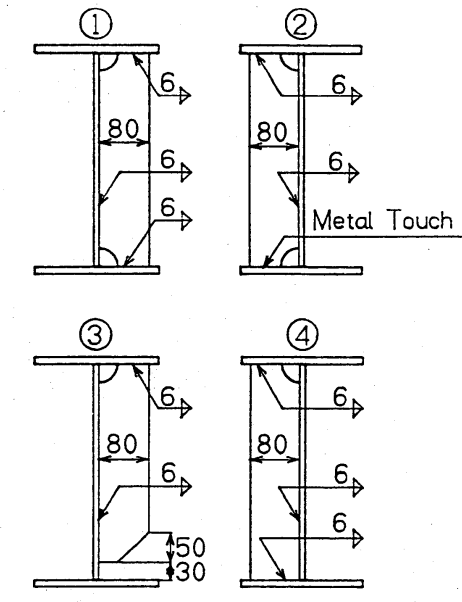

Radlus of Scallop $=30 \mathrm{~mm}$

Thlckness of Stiffener Plate $=9 \mathrm{~mm}$

Fig. 1. Plate girder specimen with transverse stiffeners (Dimension: $\mathrm{mm},{ }^{\circ}:$ Strain gage)

Table I. Mechanical properties and chemical composition of steel plates.

\begin{tabular}{c|c|c|c|c|c|c|c|c|c}
\hline \multirow{2}{*}{ Material } & \multirow{2}{*}{$\begin{array}{c}\text { Thickness } \\
(\mathrm{mm})\end{array}$} & \multicolumn{3}{|c|}{ Mechanical properties } & \multicolumn{5}{c}{ Chemical composition (\%) } \\
\cline { 3 - 9 } & $\begin{array}{c}\text { Y.P. } \\
(\mathrm{MPa})\end{array}$ & $\begin{array}{c}\text { T. S. } \\
(\mathrm{MPa})\end{array}$ & $\begin{array}{c}\text { EL. } \\
(\%)\end{array}$ & $\begin{array}{c}\mathrm{C} \\
\times 100\end{array}$ & $\begin{array}{c}\mathrm{Si} \\
\times 100\end{array}$ & $\begin{array}{c}\text { Mn } \\
\times 100\end{array}$ & $\begin{array}{c}\mathrm{P} \\
\times 1000\end{array}$ & $\begin{array}{c}\mathrm{S} \\
\times 1000\end{array}$ \\
\hline SM490A & 12 & 363 & 510 & 29 & 16 & 35 & 124 & 24 & 22 \\
SM490A & 9 & 363 & 519 & 26 & 16 & 39 & 144 & 16 & 3 \\
SS400 & 9 & 284 & 431 & 30 & 14 & 15 & 65 & 17 & 3 \\
\hline
\end{tabular}

Table II. Welding conditions.

\begin{tabular}{c|c|c|c|c}
\hline $\begin{array}{c}\text { Welding } \\
\text { method }\end{array}$ & $\begin{array}{c}\text { Current } \\
(\mathrm{A})\end{array}$ & $\begin{array}{c}\text { Voltage } \\
(\mathrm{V})\end{array}$ & $\begin{array}{c}\text { Speed } \\
(\mathrm{cm} / \mathrm{min})\end{array}$ & $\begin{array}{c}\text { Heat input } \\
(\mathrm{kJ} / \mathrm{cm})\end{array}$ \\
\hline Submerged Arc & 650 & 35 & 60 & 23 \\
\hline $\mathrm{CO}_{2}$ Arc & 250 & 28 & $20 \sim 26$ & $16 \sim 21$ \\
\hline
\end{tabular}

(3) 引張フランジと $30 \mathrm{~mm}$ の間隔をあけて取付ける

(4) スカーラップなしで引張フランジと溶接する

なお，垂直補剛材の取付け位置は，各ディテールについ て疲労き裂の発生が予想される位置（ディテール (1) と (4)では下フランジ上面の溶接止端, ディテール (2) と (3) では補剛材下端部ウェブ側の溶接止端）の公称応力が等 しくなるように決定した．また，Fig.1の。印の位置に ひずみゲージを貼付し，試験部に作用する公称応力を測 定した。

ウェブおよびフランジは板厚が $9 \mathrm{~mm}$ および $12 \mathrm{~mm}$ の JIS SM490A, 補剛材は板厚 $9 \mathrm{~mm} の$ JIS SS400 で ある. ウェブとフランジの組立てはソリッドワイヤ (YS-S6) およびフラックス (FS-FP1) を用いたサブマ ージアーク溶接, 補剛材の取付けはフラックス入りワイ ヤ (YFW24)を用いた $\mathrm{CO}_{2}$ ガスシールドアーク溶接によ り行った．使用鋼材の機械的性質と化学成分を Table I に，溶接条件を Table II に示す.

\section{$2 \cdot 2$ 変動荷重}

道路橋の実働荷重をできるだけ忠実に再現するために コンピュータシミュレーションによって発生させた変動 荷重波形を用いた。シミュレーションの条件として大型 車混入率が非常に高く（実測データのほぼ上限として $85 \%$ ), 複数車両の同時載荷の影響が大きい 2 車線の橋 梁を仮定した. シミュレーションによって発生させた変
動荷重波形に対し，レインフロー法を用いて求めた変動 応力範囲の頻度分布を Fig. 2 に示す. 本研究ではシミュ レーションで得られた波形から，最大応力範囲の $1 \%$ 以下の極めて微小な応力範囲成分（相対頻度 $19.5 \%$ ） と $65 \%$ 以上の極めて低頻度の高応力範囲成分（相対頻 度 $0.4 \%$ ）を削除した。応力範囲頻度分布の 3 乗平均の 3 乗根として得られる等価応力範囲の最大応力範囲に対 する比 $\left(S r_{e q} / S r_{\text {max }}\right)$ は，削除前 0.27 に対し，削除後は 0.45 となる. $65 \%$ の 0.45 は 0.29 であるから $S r_{e q}$ 自体 はほとんど変化していない.Fig. 3 には疲労試験に用い た削除後の変動荷重波形の一部を示す.

\section{$2 \cdot 3$ 疲労試験}

疲労試験は電気油圧式疲労試験機（動的能力 \pm 400 $\mathrm{kN}$ ）を用いた 3 点曲げ載荷により行った. 疲労試験機 の制御は D/A コンバータを介し，パーソナルコンピュ

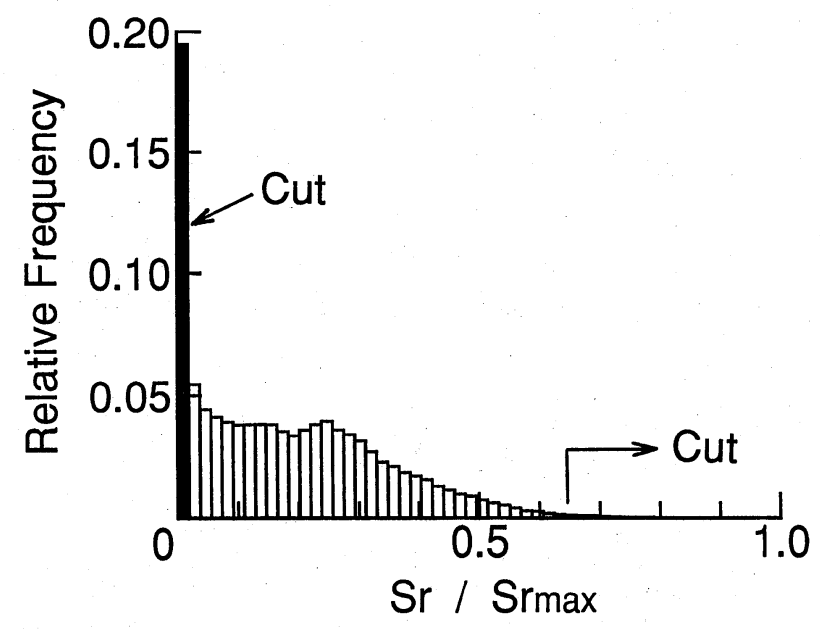

Fig. 2. Stress range histogram. 


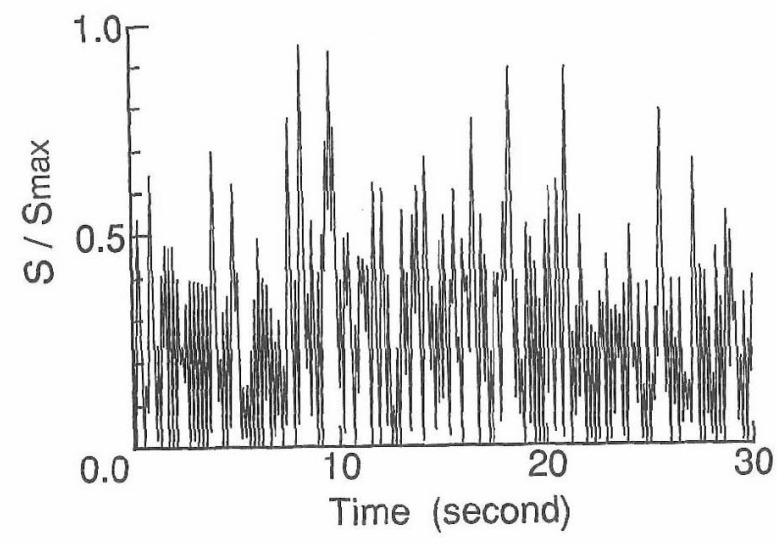

Fig. 3. Variable amplitude loading wave form.

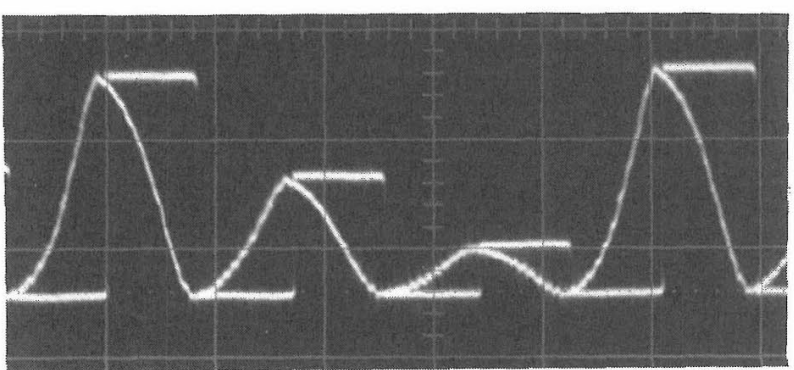

Fig. 4. Input signal and output response of variable amplitude loading.

一夕により行った。疲労試験中のコンピュータからの変 動荷重の制御信号（矩形波）と実働荷重波形を Fig. 4 に 示す. 応力繰返し速度は $5 \mathrm{~Hz}$ である.

また，疲労き裂の発生と進展挙動を調べるため，疲労 き裂の発生が予想される溶接部について目視，浸透探傷 法および磁粉探傷法によりき裂の検出を試みた。き裂が 成長してフランジが破断した場合には，高力ボルトによ る添接補強とストップホールに高力ボルト締めを併用し て試験を続行した。

\section{3 疲労き裂の発生・進展挙動}

Table III に疲学試験結果, Fig. 5 に両方の試験体の痕 Table III. Fatigue test results.

\begin{tabular}{|c|c|c|c|c|c|}
\hline Spec. & Detail & $\begin{array}{c}S r_{e q} \\
(\mathrm{MPa})\end{array}$ & $\begin{array}{c}2 b_{d} \\
(\mathrm{~mm})\end{array}$ & ${ }^{N d}$ & $\stackrel{N f}{N \text { cles) }}$ \\
\hline \multirow{9}{*}{ No. 4} & (1) & $55^{*}$ & 15 & 7.3 & 12.9 \\
\hline & (2) & 71 & - & $>10.6$ & $>10.6$ \\
\hline & (3) & 69 & 8 & 9.0 & 12.9 \\
\hline & (4) & 70 & 5 & 5.2 & 12.9 \\
\hline & $\mathrm{BH}$ & 99 & 200 & 10.6 & 18.5 \\
\hline & (1) (Comp.) & 84 & 23,33 & 12.9 & 12.9 \\
\hline & (1) (Comp.) & $70^{*}$ & 10 & 12.9 & 12.9 \\
\hline & (1) (Comp.) & 70 & - & $>12.9$ & $>12.9$ \\
\hline & $\begin{array}{c}\text { Attachment } \\
\text { (Comp.) }\end{array}$ & 98 & 53,93 & 12.9 & 12.9 \\
\hline \multirow{7}{*}{ No. 5} & (1) & $50 *$ & 9 & 9.0 & 21.5 \\
\hline & (2) & 59 & 3 & 11.1 & 12.3 \\
\hline & (3) & 60 & 4 & 6.4 & 17.6 \\
\hline & (4) & 58 & 30 & 13.5 & 13.5 \\
\hline & (1) (Comp.) & 71 & $\begin{array}{l}30,40 \\
38,38\end{array}$ & 21.5 & 21.5 \\
\hline & (1) (Comp.) & 59 & - & $>21.5$ & $>21.5$ \\
\hline & $\begin{array}{l}\text { Attachment } \\
\text { (Comp.) }\end{array}$ & 84 & 68,82 & 21.5 & 21.5 \\
\hline
\end{tabular}

* : Stress range at the stiffener end on web plate.

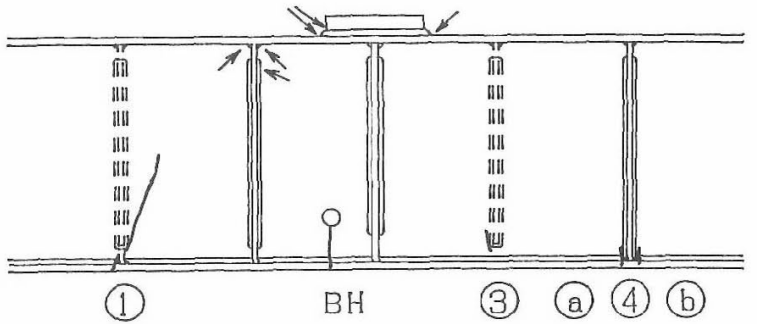

(a) Specimen No. 4 .

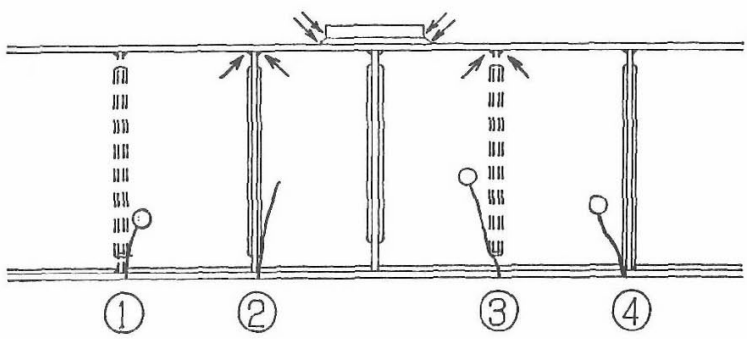

(b) Specimen No. 5

Fig. 5. Location of fatigue cracking.

労き裂発生状況を示す. $S r_{\text {eq }}$ は Fig. 1 に示したひずみ ゲージによって測定された公称応力值からそれぞれのき 裂発生位置について求めた等価応力範囲， $2 b_{d}$ は発見光 れたき裂の表面長さ，Nd はき裂発見時の荷重繰返し数， $N f$ はき裂が板厚を貫通して Fig. 5 に示すようなある程 度の大きさになった時の荷重繰返し数で定義した継手部 の破断寿命である。

試験体 No. 4 では，疲労き裂は 500 万回から 900 万回

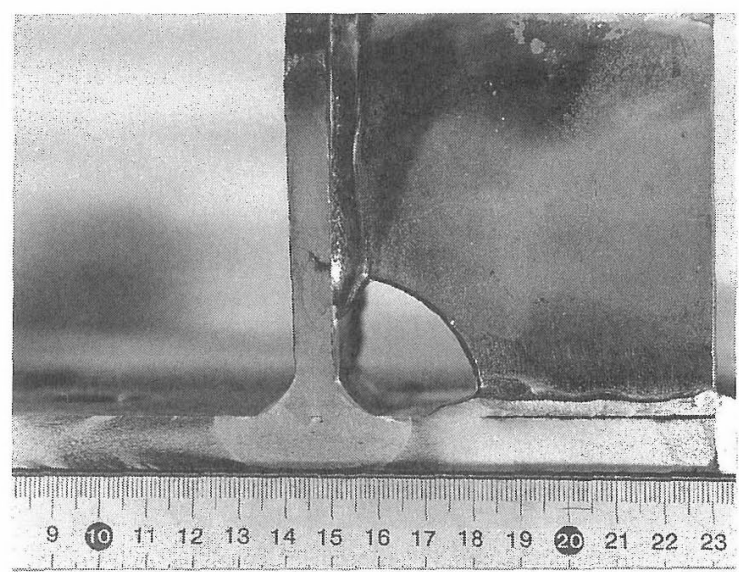

(a) Detail (1) (Specimen No. 5).

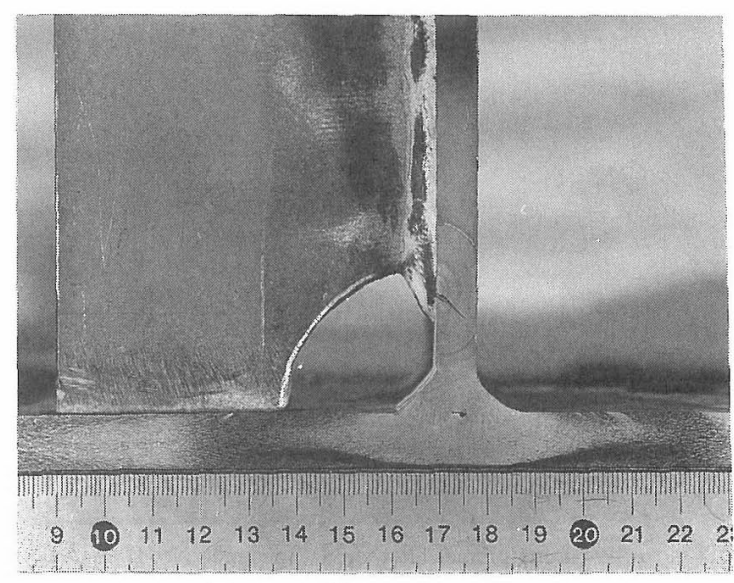

(b) Detail (2) (Specimen No.5). 
程度の間にディテール (4)，(1)，(3) の順序で発見され、 1000 万回を越えたところでウェブとフランジを接合す る縦方向すみ肉溶接部に生じたき裂により下フランジが 破断したためにいったん試験を中断した。高力ボルトに よる補強後試験を続行したが，約 1300 万回でディテー ル (1) が破断したために試験を終了した。試験体No. 5 では，600万回から 1400 万回までの間にディテール (3)，(1)，(2)，(4) と試験体 No.4 と逆の順序でき裂が発見 され，1200万回から 2200 万回の間ですべてのディテ ールが破断している。

Fig. 6 は各ディテールの痩労破面を示したものである 疲労き裂の発生位置は両試験体，各ディテールとも一定

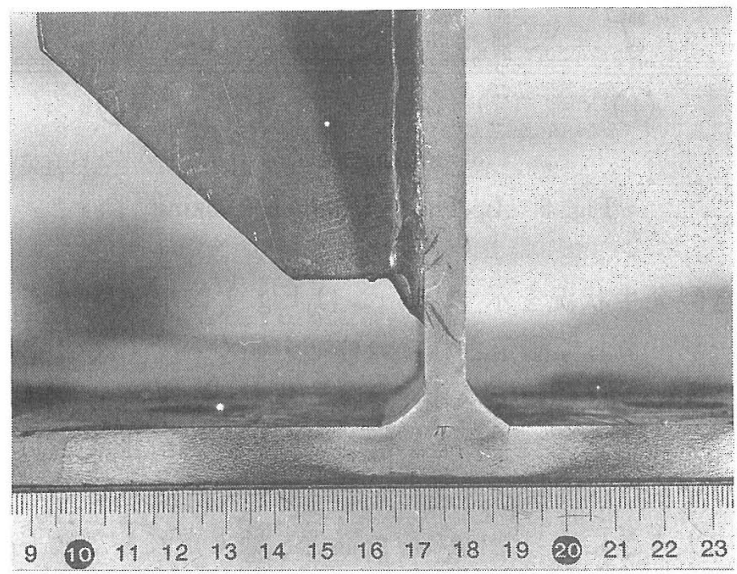

(c) Detail (3) (Specimen No. 5).

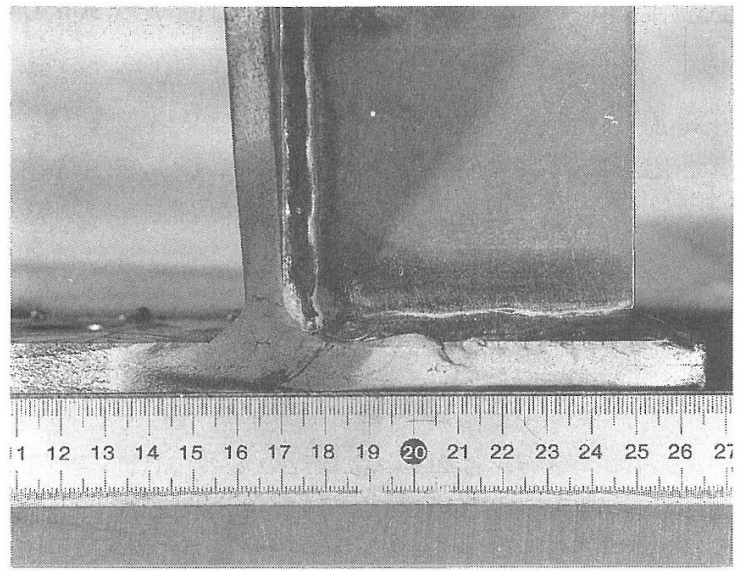

(d) Detail (4) (Specimen No. 5).

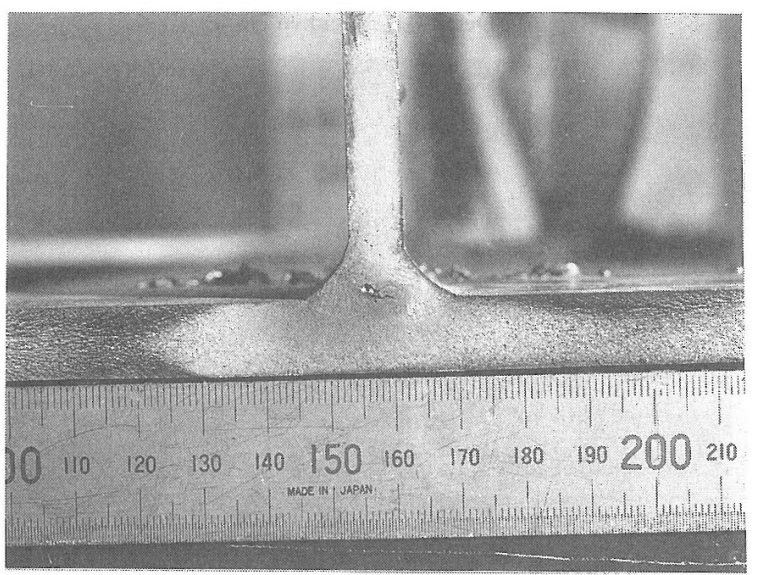

(e) Longitudinal fillet weld. (Specimen No. 4).

Fig. 6. Fatigue fracture surfaces.
振幅荷重の場合亡同様である。すなわち,ディテール (1), (2)，(3)では垂直補剛材下端部のウェブ側の溶接止端， ディテール (4)ではウェブとフランジを接合する縦方向 溶接と補剛材を取付ける横方向溶接の交差部の溶接止端 である。ウェブーフランジ間の縦方向溶接部の破面上に は，最大幅 $1.2 \mathrm{~mm}$ ，長さ $3.1 \mathrm{~mm}$ のブローホールが認 められる。

Fig. 5 中の矢印は疲労試験終了後に圧縮側で検出した 疲労き裂を示している。各き裂の写真をFig.7 に示す。 疲学き裂は垂直補剛材上端部のウエブ側とフランジ側の 溶接止端，および圧縮フランジ上面の載荷板の前面すみ 肉溶接部で生じているが，いずれも溶接部内に留まって

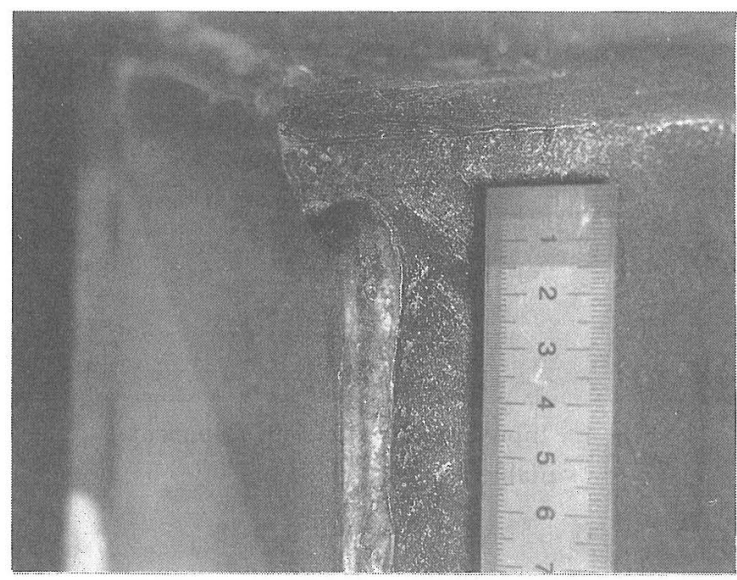

(a) Stiffener end on web (Specimen No. 4).

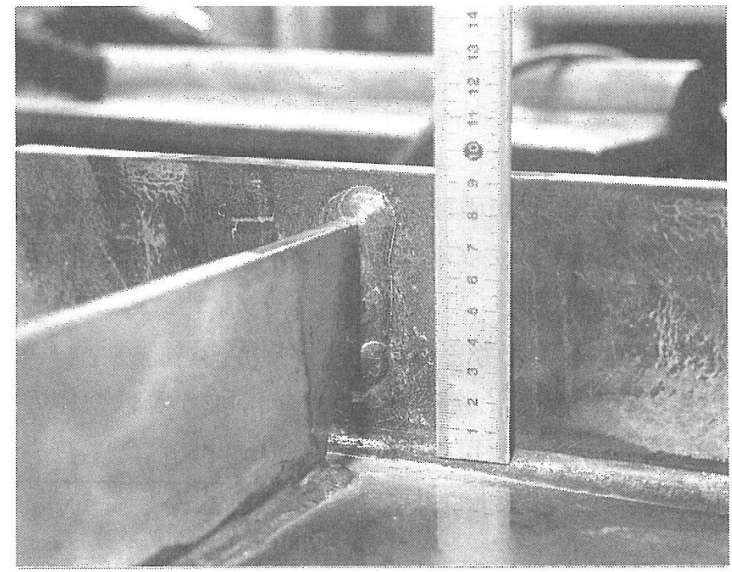

(b) Stiffener end on top flange (Specimen No. 4).

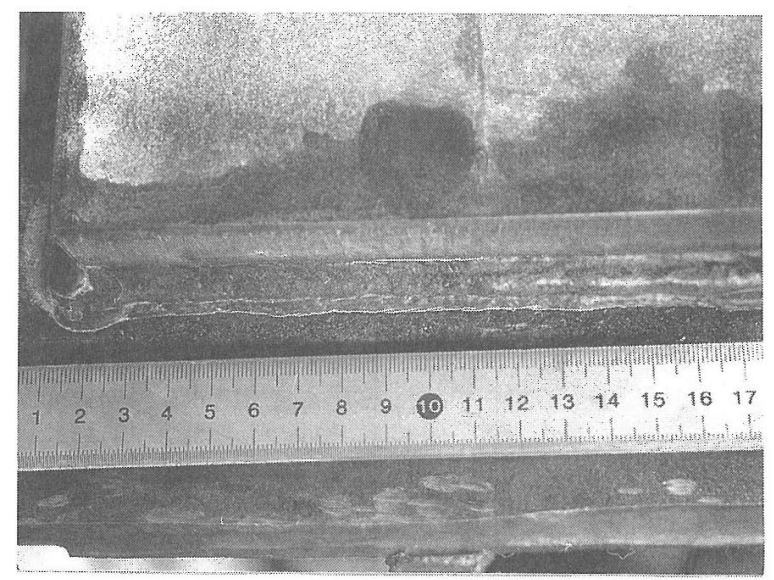

(c) Attachment end on top flange (Specimen No. 5).

Fig. 7. Fatigue cracks in compression area. 
いる.

\section{4 疲 労 強 度}

Fig. 8 と Fig. 9 に，き裂発生位置の公称等価応力範囲 $S r_{e q}$ とき裂発見寿命 $N d$ ，およびフランジ破断寿命 $N f$ の関係をそれぞれ示す。圧縮側のディテールの $N d$ と $N f$ は，それぞれ試験体の試験終了時の荷重繰返し回数 である。両図中には，JSSC 疲労設計指針のC，D，

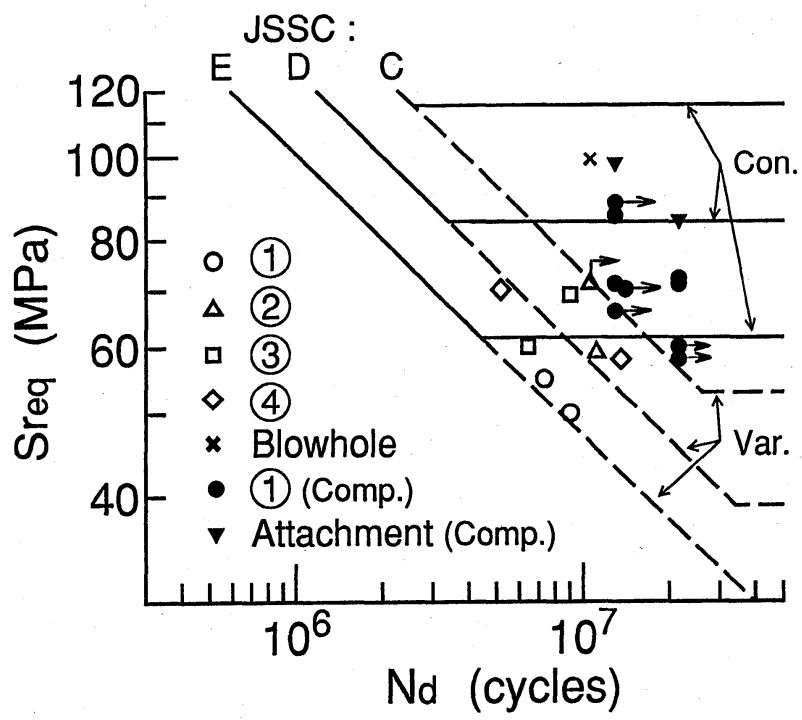

Fig. 8. Relation between equivalent stress range $S r_{e q}$ and crack detection life $N d$.

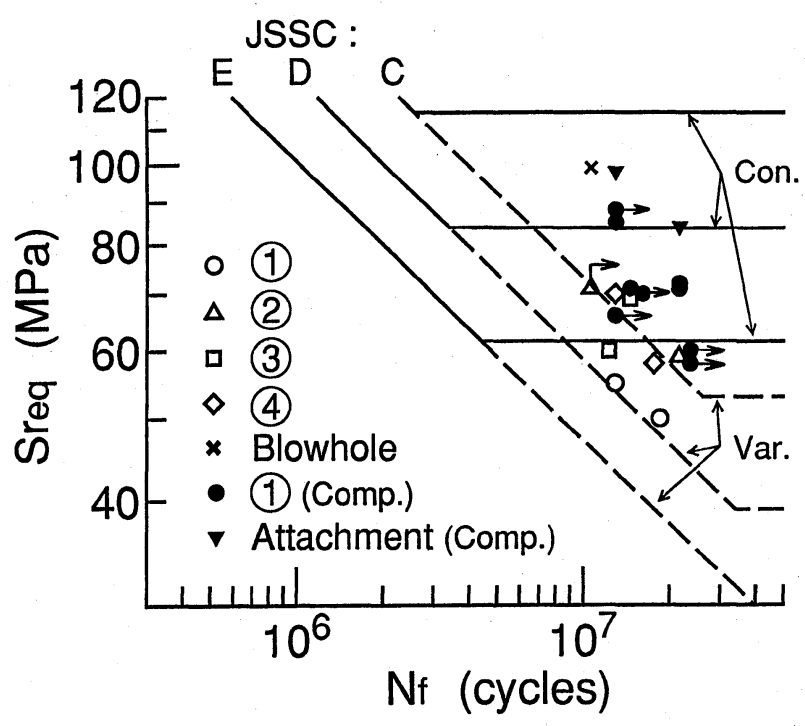

Fig. 9. Relation between equivalent stress range $S r_{e q}$ and fatigue failure life $N f$.
$\mathrm{E}$ 等級の設計寿命曲線も示してある．本試験体の補剛材 取付部は同指針では $\mathrm{E}$ 等級に分類される.

$N d$ でみると垂直補剛材取付け部の引張側ディテール の疲労強度は $\mathrm{C}$ 等級から $\mathrm{E}$ 等級まで広く分布するが, $N f$ を基準とすればばらつきが小さくなり，それらの疲 労強度は 1 ランク上のD等級をすべて満たしている。一 定振幅荷重下では (3) の疲労限が最も高く (4) が最も低 かったが, 今回の実験結果にその傾向は現れていない.

むしろ (2) が高く (1) が低い傾向があるが, この程度の違 いは疲労寿命のばらつきの範囲内とみるべきであろう.

ブローホールから疲労き裂が生じた縦方向すみ肉溶接 部の疲労強度は, 幅 $1.5 \mathrm{~mm}$, 長さ $4 \mathrm{~mm}$ 以下の欠陥が 許容されるC等級を十分に満たしている.

また，圧縮側の継手部の疲労き裂については，溶接部 内に留まっているき裂に対して試験終了時の繰返し数を プロットしたものであることから，実際のき裂発生寿命 は Fig. 8 よりも短寿命側で, 破断寿命は Fig. 9 よりも長 寿命側となる.

$$
5 \text { おわりに }
$$

4 種類の垂直補剛材取付部をもつプレートガーダー試 験体を用い, 道路橋シミュレーション変動荷重下の疲労 実験を行った．その結果, 一定振幅荷重疲労試験でみら れたような垂直補剛材取付部のディテールの違いによる 疲労強度の違いは認められず，継手部の破断寿命を基準 とすれば，すべての垂直補剛材取付部の疲労強度は $\mathrm{JSSC}$ 疲労設計指針で推奨される $\mathrm{E}$ 等級よりも 1 ラン ク上の D 等級を満足することが示された。

なお，本研究を行うにあたり関西大学学術研究助成基 金および文部省科学研究費補助金による助成を受けた. 末筆ながら記して謝意を表する次第である.

（平成 5 年11月 24 日 日本材料学会第 4 回機械・構造物の強度設計, 安 全性評価シンポジウムにて講演)

\section{参 考 文. 献}

1 ) 日本道路協会, “道路橋示方書・同解説（I 共通編 - II 鋼 橋編)”, p. 254 (1990).

2 ）日本鋼構造協会, “鋼構造物の疲労設計指針 - 同解説” （1993）技報堂.

3 ) 坂野昌弘, 三上市藏, 米本栄一, 安池寿夫, 構造工学論文 集, 38 A, 999 (1992).

4 ）坂野昌弘, 三上市藏, 宮川欣也, 構造工学論文集, $38 \mathrm{~A}$, 1063 (1992). 